\title{
EKSPRESI GEN PROTEIN SELUBUNG TOMATO INFECTIOUS CHLOROSIS VIRUS PADA ESCHERICHIA COLI
}

\author{
Fitrianingrum Kurniawati, Gede Suastika, \& Giyanto \\ Departemen Proteksi Tanaman, Fakultas Pertanian, Institut Pertanian Bogor \\ Jl. Kamper, Kampus IPB Dramaga, Bogor 16680 \\ E-mail: fitrianingrumk@gmail.com
}

\begin{abstract}
Expression of tomato infectious chlorosis virus coat protein gene on Escherichia coli. Tomato infectious chlorosis virus (TICV) is the causal agent of chlorotic disease of tomato. Detection of TICV can be carried out by RT-PCR and serological test. Titer of TICV in plant tissue is very low because TICV is limited to phloem. Serological detection of TICV requires antiserum which is not available in Indonesia. Producing antibody through cloning and coat protein gene (TICV CP gene) expression is a promising approach in producing antiserum. The objective of this study was to express TICV CP gene as antigen for antiserum production. TICV CP gene was amplified using RT-PCR from total RNA extracted from TICV infected leaves collected from Cipanas, Cianjur, West Java. The amplified CP gene was then sequenced and sub-cloned into pET $21 \mathrm{~b}$ expression vector, transformed into Escherichia coli strain BL21 DE3(pLysS) and induced expression using IPTG 1 mM overnight at $37^{\circ} \mathrm{C}$. CP that contains 6xhistag was purified using NiNTA spin column and then confirmed by SDS-PAGE. The size of TICV CP gene was $750 \mathrm{bp}$ and the gene was expressed on pET $21 \mathrm{~b}$ vector and SDS-PAGE showed a $29 \mathrm{kDa}$ band.
\end{abstract}

Key words: coat protein gene, expression, tomato infectious chlorosis virus (TICV)

\begin{abstract}
ABSTRAK
Ekspresi gen protein selubung tomato infectious chlorosis virus pada Escherichia coli. Penyakit klorosis pada tanaman tomat disebabkan oleh Tomato infectious chlorosis virus (TICV). Deteksi TICV dapat dilakukan dengan transkripsi balik (RTPCR) dan serologi. Titer TICV dalam jaringan tanaman sangat rendah karena terbatas pada jaringan floem. Deteksi serologi membutuhkan antiserum. Di Indonesia antiserum TICV ini belum tersedia. Usaha penyediaan antigen melalui kloning dan ekspresi gen protein selubung (CP) merupakan salah satu cara yang menjanjikan dalam produksi antiserum. Penelitian ini bertujuan untuk mengekspresikan gen CP TICV sebagai antigen dalam produksi antiserum. Gen CP diamplifikasi dengan transkripsi balik (RT-PCR) dari RNA total yang diekstraksi dari daun yang terinfeksi yang berasal dari Cipanas, Kabupaten Cianjur, Jawa Barat. Gen CP hasil amplifikasi kemudian di sekuensing, disubkloning ke dalam vektor ekspresi pET 21b, ditransformasi ke dalam bakteri Escherichia coli strain BL21 DE3(pLysS) dan diekspresikan dengan diinduksi menggunakan IPTG $1 \mathrm{mM}$ selama semalaman pada suhu $37^{\circ} \mathrm{C}$. Purifikasi CP yang mengandung 6xhistag dengan menggunakan NiNTA spin column dan hasilnya dikonfirmasi dengan sodium deodecyl sulphate polyacrilamide gel electrophoresis (SDS-PAGE). Hasil amplifikasi gen CP berhasil memperoleh fragmen gen CP yang berukuran $750 \mathrm{pb}$ dan diekspresikan pada vektor pET $21 \mathrm{~b}$. Purifikasi CP yang mengandung 6xhistag menggunakan NiNTA spin column berhasil memperoleh pita CP yang berukuran sekitar $29 \mathrm{kDa}$.
\end{abstract}

Kata kunci: ekspresi, gen protein selubung, tomato infectious chlorosis virus (TICV)

\section{PENDAHULUAN}

Tomato infectious chlorosis virus (TICV) merupakan salah satu virus yang menyebabkan penyakit klorosis pada tanaman tomat. Di Indonesia, penyakit ini telah ditemukan di beberapa sentra produksi tomat, seperti di Garut, Cipanas-Cianjur, Bogor, Magelang, dan Yogyakarta (Sa'adah, 2013; Fitriasari, 2010; Hartono \& Wijonarko, 2007). TICV merupakan anggota dari genus Crinivirus (famili Closteroviridae) (Jacquemond et al., 2009).

Gejala serangan TICV pada tanaman tomat ditunjukkan oleh klorosis pada bagian antara tulang daun. Jika gejala klorosis sangat parah, daun akan mengalami nekrotik (kematian jaringan) dan menjadi rapuh, serta ukuran buah menjadi lebih kecil, mudah gugur dan proses pemasakan terganggu sehingga hasil panen menurun (Wisler et al., 1998). TICV ditularkan dari satu tanaman 
ke tanaman lainnya oleh serangga vektor Trialeurodes vaporariorum (Hemiptera: Aleyrodidae) yang dikenal dengan nama kutu kebul rumah kaca secara semipersisten (Duffus et al., 1996).

Deteksi TICV dapat dilakukan dengan reverse transcription-polymerase chain reaction (RT-PCR) dan hasilnya sangat cepat dan akurat, tetapi deteksi tersebut memerlukan bahan-bahan dan peralatan yang mahal. Teknik deteksi selain RT-PCR adalah deteksi dengan pendekatan serologi yaitu enzyme linked immunosorbent assay (ELISA), tissue blot immunosorbent assay (TBIA), dan dot blot immunosorbent assay (DIBA). Deteksi dengan metode ini cepat dan murah. Deteksi secara serologi ini memerlukan antiserum. Antiserum TICV belum tersedia di Indonesia, sehingga menyulitkan dalam mendeteksi virus ini. Usaha ke arah penyediaan antiserum akan sangat bermanfaat sebagai sarana dalam mendeteksi TICV. Titer TICV pada tanaman sangat rendah karena virus ini hanya ditemukan pada jaringan floem.

Ekspresi gen coat protein (CP) TICV pada Escherichia coli menjanjikan tersedianya antigen dalam jumlah yang cukup untuk produksi antiserum. Keunggulan penyediaan antiserum dengan metode ini antara lain: protein yang dihasilkan bersifat spesifik sehingga tidak bereaksi terhadap protein tanaman, antigen dapat tersedia dalam jumlah yang mencukupi setiap saat apabila diperlukan untuk produksi antiserum (Cotillon et al., 2005). Melihat keunggulan di atas maka diperlukan suatu metode untuk dapat mengekspresikan gen CP-TICV yang akan digunakan sebagai antigen dalam produksi antiserum. Penelitian ini bertujuan untuk mengekspresikan gen protein selubung (CP) TICV pada E. coli. Manfaat dari penelitian ini berupa protein selubung TICV murni yang dapat digunakan sebagai antigen pada tubuh mamalia (kelinci) sehingga terbentuk antibodi terhadap TICV yang kemudian dapat digunakan sebagai sarana deteksi virus yang bersangkutan.

\section{METODE PENELITIAN}

Tempat dan Waktu. Penelitian ini dilakukan di Laboratorium Virologi Tumbuhan, Departemen Proteksi Tanaman, Fakultas Pertanian IPB dan Laboratorium Biokimia Balai Besar Bioteknologi dan Sumberdaya Genetik Pertanian dari bulan Mei 2012 sampai dengan Agustus 2013.

Tanaman Sumber Virus. Untuk mendapatkan TICV isolat Indonesia dilakukan pengumpulan tanaman bergejala klorosis dari sentra produksi tomat di daerah
Cipanas, Kabupaten Cianjur, Provinsi Jawa Barat (1225 $\mathrm{m}$ dpl). Daun tanaman yang terinfeksi TICV diamati dan difoto gejalanya, kemudian diambil untuk diidentifikasi dengan menggunakan transkripsi balik (RTPCR).

\section{Amplifikasi Gen CP TICV}

Ekstraksi RNA Total. Ekstraksi RNA total dilakukan dengan menggunakan Qiagen RNAeasy Plant Mini Kit dan dikerjakan sesuai dengan protokol yang diberikan (Qiagen, 2003).

Sintesis complementary (c) DNA. RNA hasil ekstraksi digunakan sebagai cetakan dalam sintesis cDNA melalui reaksi RT mengikuti metode Fitriasari (2010). Siapan cDNA hasil RT digunakan sebagai cetakan dalam reaksi PCR.

PCR. PCR dilakukan dalam volume $25 \mu \mathrm{l}$ yang terdiri dari 12,5 $\mu 1$ Go Tag Green PCR Master mix (Thermo Scientific, US), masing-masing $1 \mu \mathrm{l}$ primer (TICV-CP F-Bam no ATG (5'A A $T$ T A A G G A T C C G A A A A CTTATCTGGTAATGCAAAC-3' dan TICV-CP RHind 5'-AATTAAAAGCTTTTAGCATGGGTG TTTCATATC AGCC-3'), 8,5 $\mu$ l ddH ${ }_{2} \mathrm{O}$ dan $2 \mu \mathrm{l}$ cDNA. PCR dilakukan pada Automated Thermal cycler (Gene Amp PCR System 9700; PE Applied Biosystem, USA). Proses ini didahului dengan denaturasi awal pada $94^{\circ} \mathrm{C}$ selama 4 menit, dilanjutkan dengan 30 siklus yang terdiri dari denaturasi pada $94{ }^{\circ} \mathrm{C}$ selama 1 menit, penempelan primer (annealing) pada $55{ }^{\circ} \mathrm{C}$ selama 1 menit, dan pemanjangan (extension) pada $72{ }^{\circ} \mathrm{C}$ selama 2 menit, dan diikuti pemanjangan akhir pada $72{ }^{\circ} \mathrm{C}$ selama 10 menit.

Elusi Produk PCR. Produk PCR dielektroforesis dalam gel agarose $1 \%$. Produk PCR dan penanda DNA $1 \mathrm{~kb}$ (Thermo Scientific, US), masingmasing $10 \mu \mathrm{l}$ dan $5 \mu \mathrm{l}$ dimasukkan ke dalam sumuran yang telah disiapkan pada gel agarose. Elektroforesis dilakukan selama 30 menit pada 100 V. Produk PCR yang telah dielektroforesis kemudian divisualisasi dengan UV transluminator. Bagian gel tepat pada produk PCR dipotong dan dimasukkan ke tabung mikro yang sudah ditambahkan $500 \mu \mathrm{l}$ buffer DF (HiYield, China), kemudian divortex, dan diinkubasi pada suhu $55^{\circ} \mathrm{C}$ sampai gel cair. Siapan kemudian dimasukkan ke DF kolom dan disentrifugasi dengan kecepatan 8000 rpm selama 1 menit. Selanjutnya, $500 \mu 1$ wash buffer (HiYield, China) dimasukkan dalam DF kolom dan disentrifugasi dengan kecepatan 8000 rpm selama 1 menit. Sebanyak $20 \mu 1$ buffer elusi (HiYield, China) ditambahkan pada tengah kolom dan disentrifugasi pada kecepatan 8000 rpm 
selama 1 menit. Hasil elusi (yang merupakan gen CPTICV) disimpan pada suhu $-20{ }^{\circ} \mathrm{C}$ sampai akan digunakan.

\section{Penyisipan Gen CP TICV pada Plasmid Vektor pET-21b}

Pemotongan Plasmid Vektor pET-21b. Plasmid pET-21b dipotong dengan enzim restriksi BamH1 dan HindIII. Rektan untuk pemotongan plasmid dilakukan dengan total volume $20 \mu$ l yang terdiri dari 1 $\mu 1$ plasmid pET-21b, $1 \mu 1$ enzim BamH1, $1 \mu 1$ enzim HindIII, $2 \mu \mathrm{l}$ buffer, dan $15 \mu \mathrm{lddH} 2 \mathrm{O}$. Reaksi pemotongan diinkubasi pada suhu $37^{\circ} \mathrm{C}$ selama satu malam.

Ligasi Plasmid dan Insert (Gen CP TICV). Gen CP TICV disisipkan ke dalam plasmid pET-21b melalui reaksi ligasi mengikuti prosedur (Qiagen, US). Campuran ligasi dengan total volume $10 \mu \mathrm{l}$ terdiri dari 2 $\mu 1$ plasmid pET-21b, $2 \mu 1$ hasil elusi gen CP TICV, $1 \mu 1$ enzim T4 ligase, $1 \mu \mathrm{l}$ buffer ligasi, dan $4 \mu \mathrm{lddH_{2 }} \mathrm{O}$. Reaksi ligasi dilakukan pada suhu $4{ }^{\circ} \mathrm{C}$ selama 16 jam. Hasil ligasi akan menghasilkan plasmid pET-21b yang mempunyai insert gen CP TICV, yang selanjutnya disebut plasmid pET-CP TICV.

\section{Persiapan Kompeten Sel $E$. coli strain} BL21(DE3)pLysS. Stok E. coli strain BL21(DE3) pLysS dalam gliserol digores pada media LB agar yang mengandung antibiotik ampisilin $50 \mu \mathrm{g} / \mathrm{ml}$ dan kloramfenikol $20 \mu \mathrm{g} / \mathrm{ml}$, kemudian diinkubasi pada suhu $37{ }^{\circ} \mathrm{C}$ selama satu malam. Satu kultur biakan E. coli selama satu malam dipindahkan ke dalam $5 \mathrm{ml}$ Luria Bertani (LB) broth yang mengandung antibiotik kemudian diinkubasi pada suhu $37{ }^{\circ} \mathrm{C}$ selama satu malam. Sekitar $2 \mathrm{ml}$ kultur selama satu malam tersebut diambil dan dipindahkan ke dalam $40 \mathrm{ml}$ media A(LB, $\mathrm{MgSO}_{4} 7 \mathrm{H}_{2} \mathrm{O} 10 \mathrm{mM}$, gukosa $0,2 \%$ ), lalu diinkubasi selama 2 jam. Setelah 2 jam kultur bakteri dipindahkan ke tabung falcon steril dan diinkubasi dalam es batu selama 10 menit. Biakan yang berada pada tabung falcon disentrifugasi dengan kecepatan 4000 rpm, selama 15 menit pada suhu $4{ }^{\circ} \mathrm{C}$. Supernatan dibuang dan diambil peletnya. Pelet diresuspensi dengan 2,5 $\mathrm{ml}$ media B (LB, glyserol 36\%, PEG $700012 \%$, dan $\mathrm{MgSO}_{4} 7 \mathrm{H}_{2} \mathrm{O} 12$ $\mathrm{mM}$ ). Siapan bakteri tersebut kemudian dipindahpisahkan masing-masing $100 \mu \mathrm{l}$ ke tabung eppendorf $1,5 \mathrm{ml}$ dan disimpan di freezer $-80^{\circ} \mathrm{C}$ sampai digunakan untuk transformasi (Nishimura et al., 2003). Transformasi. Transformasi dilakukan dengan mencampur $10 \mu \mathrm{l}$ hasil ligasi dengan $100 \mu \mathrm{l}$ sel kompeten BL21(DE3)pLySs. Terhadap siapan ini berturut-turut dilakukan diinkubasi dalam es batu selama 20 menit, heat shock pada suhu $42{ }^{\circ} \mathrm{C}$ selama 1 menit, lalu dipindahkan ke dalam es batu selama 2 menit, ditambahkan $500 \mu \mathrm{l}$ LB cair, dan diinkubasi dengan dishaker pada suhu $37{ }^{\circ} \mathrm{C}$ selama 4 jam, kemudian disentrifus $12.000 \mathrm{rpm} 1$ menit, supernatan dibuang, pelet dan LB yang masih tersisa sampai $100 \mu$ l dihomogenasi, dan ditumbuhkan dalam media LB agar $20 \mathrm{ml}$ yang telah diberi ampisilin $50 \mu \mathrm{g} / \mathrm{ml}$ dan kloramfenikol $20 \mu \mathrm{g} / \mathrm{ml}$. Biakan tersebut diinkubasi pada suhu $37^{\circ} \mathrm{C}$ selama satu malam (Sambrook \& Russel, 2001).

Konfirmasi Transforman. Transforman yang membawa plasmid pET-CP TICV terlebih dahulu ditumbuhkan pada $5 \mathrm{ml}$ media LB cair yang mengandung $50 \mathrm{mg} / \mathrm{ml}$ ampisilin dan $20 \mathrm{mg} / \mathrm{ml}$ kloramfenikol pada suhu $37{ }^{\circ} \mathrm{C}$ selama satu malam, kemudian plasmid diisolasi dengan metode alkalin lisis (Sambrook \& Russel, 2001). Konfirmasi dilakukan dengan memotong plasmid pET-CP TICV dan koloni PCR.

Isolasi Plasmid dengan Metode Alkalin Lisis. Satu koloni bakteri diinokulasi ke dalam $10 \mathrm{ml}$ LB dan diinkubasi selama satu malam pada suhu $37^{\circ} \mathrm{C}$, kemudian dipindahkan ke tabung eppendorf $1,5 \mathrm{ml}$ dan disentrifugasi $12.000 \mathrm{rpm}$ pada suhu $4{ }^{\circ} \mathrm{C}$ selama 2 menit. Setelah itu supernatan dibuang. Resuspensi pelet dengan $100 \mu \mathrm{l}$ larutan I (50 mM glukosa, $10 \mathrm{mM}$ EDTA, $25 \mathrm{mM}$ Tris $\mathrm{HCl} \mathrm{pH} \mathrm{8,} 2 \mathrm{mg} / \mathrm{ml}$ lisozyme (ditambahkan saat akan digunakan)), kemudian divortex, ditambahkan $200 \mu \mathrm{l}$ larutan II $(0,2 \mathrm{M} \mathrm{NaOH}, 1 \%$ SDS dibuat saat akan digunakan), divortex, ditambahkan $150 \mu 1$ larutan III (3 M NaOAc pH 4,8), tabungnya dibolak-balik agar bercampur, disentrifus $12.000 \mathrm{rpm}$ selama 5 menit. Supernatan dipindahkan ke tabung eppendorf baru, ditambahkan $300 \mu \mathrm{l}$ phenol kloroform, divortex, dan disentrifus $12.000 \mathrm{rpm} 5$ menit. Larutan yang paling atas dipindahkan ke tabung yang baru, kemudian ditambahkan etanol absolut $2 \mathrm{x}$ volume, sentrifus $12.000 \mathrm{rpm}$ selama 20 menit, supernatan dibuang, dicuci dengan $800 \mu 1$ etanol $70 \%$, vortex, disentrifus $12.000 \mathrm{rpm} 5$ menit, supernatan dibuang, pelet dikeringanginkan, kemudian diresuspensi dengan $30 \mu \mathrm{l}$ buffer TE atau $\mathrm{ddH}_{2} \mathrm{O}$ (Sambrook \& Russel, 2001).

\section{Pemotongan pET-CP TICV dengan Enzim} Restriksi. Plasmid pET-CP TICV dipotong dengan enzim restriksi BamH1 dan HindIII prosedur seperti pada restriksi yang telah diuraikan sebelumnya. Hasil restriksi dielektroforesis pada gel agarose $1 \%$ selama 30 menit dengan tegangan $100 \mathrm{~V}$. Hasil elektroforesis divisualisasikan dengan transilluminator ultraviolet dan didokumentasikan dengan kamera digital. 
Mengkulturkan $E$. coli Transforman untuk Purifikasi Protein CP-TICV. E. coli strain BL21 (DE3)pLysS yang membawa plasmid rekombinan pET21-CP diinokulasi ke dalam $3 \mathrm{ml}$ media LB yang mengandung $50 \mathrm{mg} / \mathrm{ml}$ ampisilin dan $20 \mathrm{mg} / \mathrm{ml}$ kloramfenikol. Biakan diinkubasi di dalam orbital shaker $(75 \mathrm{rpm})$ pada suhu $37{ }^{\circ} \mathrm{C}$ selama satu malam. Kemudian sebanyak $100 \mathrm{ml}$ biakan diinokulasikan ke dalam $10 \mathrm{ml}$ media LB yang mengandung antibiotik dan diinkubasikan di dalam orbital shaker $(75 \mathrm{rpm})$ pada suhu $37{ }^{\circ} \mathrm{C}$. Setelah pertumbuhan bakteri mencapai $\mathrm{OD}_{600} 0,5$ (kira-kira 5-6 jam), biakan diinduksi dengan 1 $\mathrm{mM}$ isopropil-thio-D-galaktoside (IPTG) dan diinkubasikan semalaman. Sel bakteri yang mengekpresikan protein rekombinan dipanen dengan sentrifugasi (12.000 rpm, $4{ }^{\circ} \mathrm{C}, 15$ menit) dan dilisis dengan buffer B-7M urea $300 \mu \mathrm{l}$ dan turbonuclease (Nacalai, Japan) 3 unit/ml kultur $(0,4 \mu \mathrm{l})$. Sel hasil lisis disentrifugasi dengan kecepatan $12.000 \mathrm{rpm}$ pada suhu $4{ }^{\circ} \mathrm{C}$ selama 15 menit. Protein rekombinan yang ada dalam supernatan (soluble protein) dan pelet (insoluble protein) dianalisis dengan analisis SDS-PAGE.

Purifikasi CP-TICV. Purifikasi CP-TICV dilakukan dengan Qiagen NiNTA spin column pada kondisi denaturasi dan dikerjakan sesuai dengan protokol yang diberikan (Qiagen, 2008). Setelah diperoleh protein murni, dilakukan analisis SDS-PAGE (Laemmli, 1970). Elektroforesis dilakukan dengan Biorad power pac 300 selama 2 jam dengan voltase $150 \mathrm{~V}$. Kemudian gel hasil elektroforesis dilepas dari cetakannya dan dimasukkan ke dalam larutan staining (coomassie brilliant blue R250, metanol, asam asetat glasial) dan dishaker selama satu malam, setelah itu dicuci dengan larutan distaining (metanol, asam asetat glasial, aquadest) sampai gel terlihat bening dan pita protein terlihat berwarna biru selanjutnya hasilnya difoto.

\section{HASIL DAN PEMBAHASAN}

TICV Isolat Indonesia. Pengumpulan tanaman yang bergejala klorosis yang dilakukan di daerah Cipanas, Kabupaten Cianjur, Provinsi Jawa Barat berhasil mendapatkan tanaman tomat yang terinfeksi TICV (Gambar 1). Gejala penyakit klorosis pada tanaman tomat ditunjukkan oleh klorosis pada bagian tulang daun (interveinal yellowing) yang dimulai pada daun terbawah, kemudian berkembang cepat secara merata ke daun-daun bagian atas. Serangan klorosis yang parah akan menyebabkan nekrotik pada daun (Gambar 1B). Hal ini menyebabkan proses fotosintesis terganggu dan mengakibatkan penurunan produksi (Wisler et al., 1998).

Amplifikasi Gen CP TICV. Gen CP berhasil diamplifikasi menggunakan sepasang primer spesifik (TICV-CP F-Bam no ATG (5' AATTAAGGATCCG AAAACTTATCTGGTAATGCAAAC-3' dan TICVCP R-Hind 5'AATTAAAAGCTTTTAGCAT GGGTGTTTCATATCAGCC-3'). Produk PCR berukuran sekitar $750 \mathrm{pb}$ yang disajikan dalam Gambar 2, sesuai dengan hasil penelitian Fitriasari (2010). Fragmen gen CP hasil amplifikasi ini telah disekuensing (data tidak ditampilkan) dan mempunyai kemiripan dengan isolat dari negara lain sebesar 99,4-100\%. Fragmen gen $\mathrm{CP}$ ini selanjutnya digunakan pada tahap berikutnya yaitu kloning gen CP TICV.

Kloning Gen CPTICV. Proses ligasi dan transformasi merupakan tahapan utama dalam kloning gen. Penggabungan fragmen gen CP TICV ke dalam vektor ekspresi pET-21 b merupakan proses ligasi. Hasil ligasi antara vektor ekspresi (pET-21b) dengan fragmen gen CP TICV diintroduksikan ke dalam bakteri E. coli sebagai inangnya yang kemudian ditumbuhkan ke dalam media LB agar yang telah diberi antibiotik tertentu.
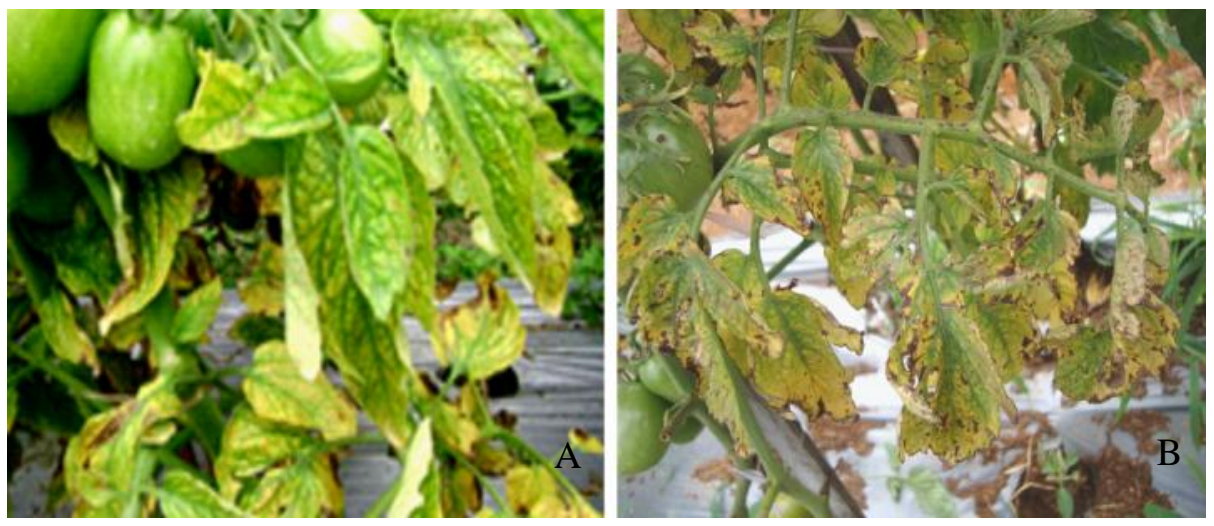

Gambar 1. Gejala penyakit klorosis pada tanaman tomat di lapangan, (A) interveinal yellowing, (B) nekrotik (Kurniawati et al., 2015) 


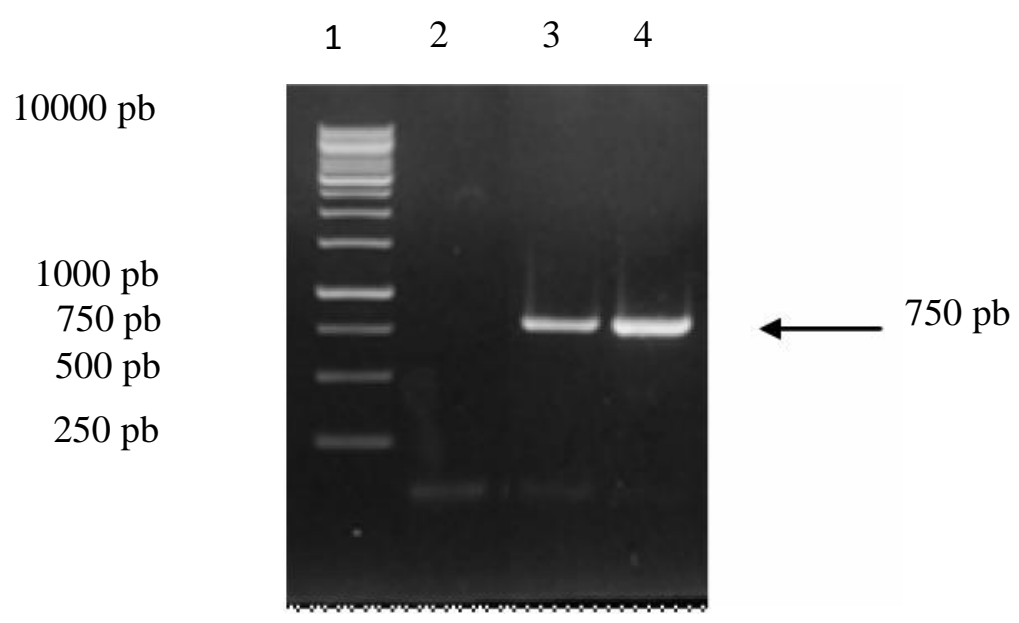

Gambar 2. Hasil amplifikasi gen CP TICV berukuran sekitar 750 bp melalui RT-PCR terhadap sampel tanaman tomat dari Cipanas (C) (lajur 4) menggunakan primer spesifik. Lajur M adalah $1 \mathrm{~kb}$ DNA ladder (Thermo Scientific, US) (Lajur 1), kontrol negatif (Lajur 2), kontrol positif (Lajur 3) (sampel tanaman cabai terinfeksi asal Cipanas hasil penelitian Fitriasari (2010))
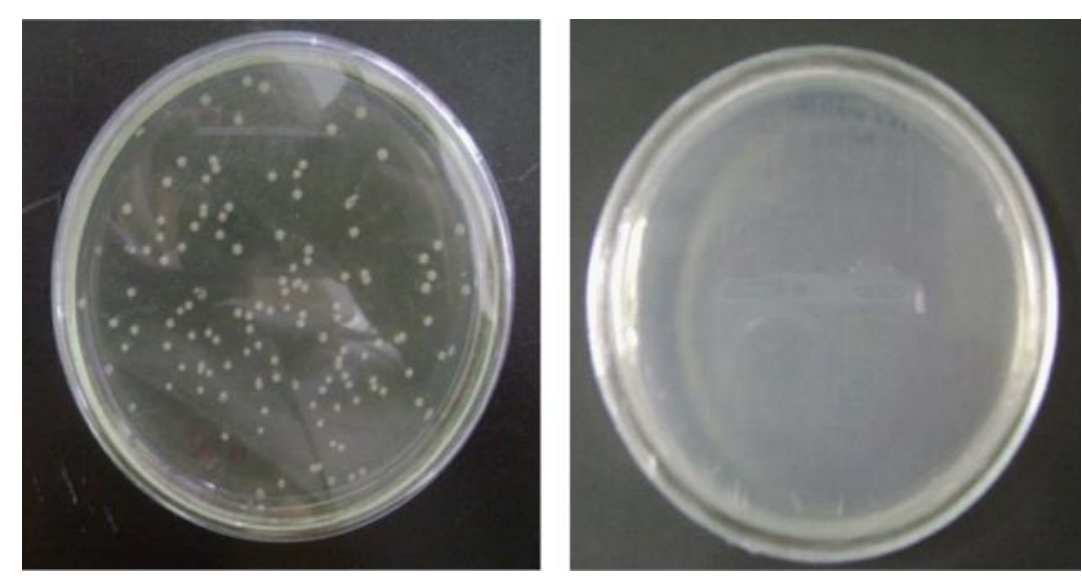

Gambar 3. (A) Koloni E. coli BL21 (DE3) pLysS yang membawa plasmid rekombinan pET21-CP pada media LB agar yang telah diberi antibiotik ampisilin dan kloramfenikol, (B) kontrol berupa plasmid pET-21 b tanpa insert yang ditumbuhkan pada LB agar yang telah diberi antibiotik ampisilin dan kloramfenikol

Keberhasilan dalam proses transformasi dapat dilihat dari kemampuan tumbuhnya $E$. coli pada media selektif (LB agar yang telah diberi antibiotik ampisilin dan klorampenikol). Keberhasilan proses ligasi dapat dilihat dari adanya koloni yang berwarna putih. Menurut Sambrook \& Russel (2001) sel bakteri yang mengandung plasmid yang membawa sisipan DNA akan berwarna putih (Gambar 3).

Konfirmasi Transforman. Plasmid rekombinan pET21CP yang membawa gen CP-TICV berhasil dikonstruksi dengan menyisipkan gen tersebut pada situs pemotongan
BamHI/HindIII. Hasil pemotongan plasmid rekombinan pET21-CP dengan BamHI/HindIII menghasilkan dua fragmen berukuran $5400 \mathrm{bp}$ dan $750 \mathrm{bp}$ yang masingmasing adalah vektor ekspresi pET-21b dan gen CP TICV (Gambar 4A). Kedudukan gen terletak antara T7 setelah start kodon dengan his-tag sebelum stop kodon. Fusi his-tag ke dalam protein target berfungsi untuk proses purifikasi dan deteksi protein rekombinan yang diekspresikan. Klon E. coli strain BL21(DE3)pLysS yang positif membawa plasmid rekombinan telah berhasil diseleksi dengan PCR (Gambar 4B). Satu fragmen tunggal dengan ukuran 


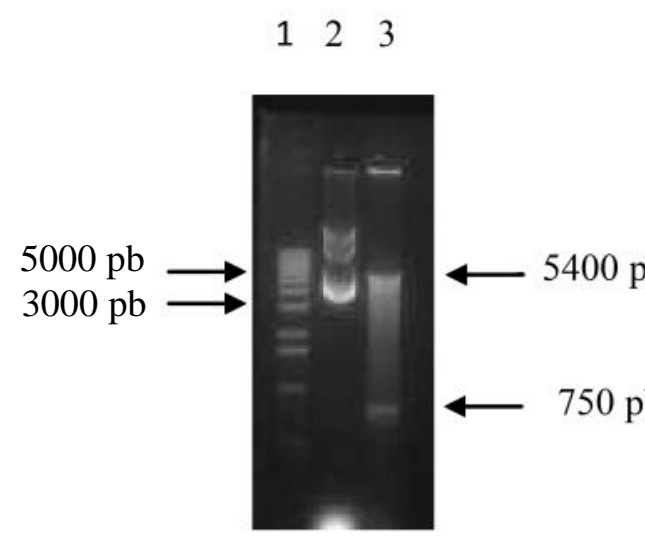

A $\begin{array}{llllll}1 & 2 & 3 & 4 & 5 & 6\end{array}$

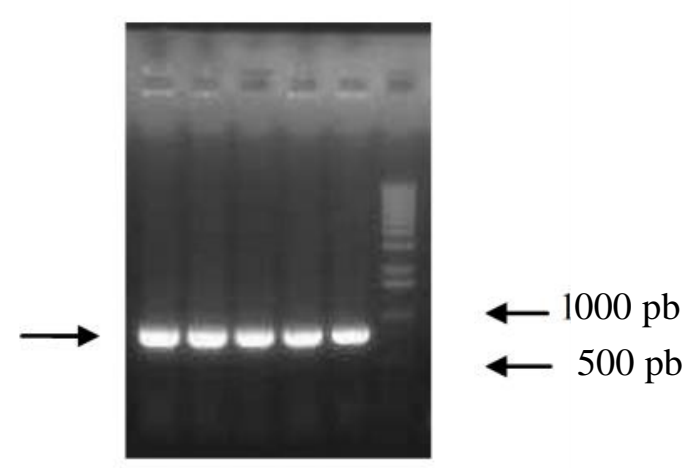

B

Gambar 4. Hasil elektroforesıs pada $1 \%$ agarose dari (A) pemotonyan plasmrid rekumbinan pET21b-CP TICV dengan enzim restriksi BamHI dan HindIII. Lajur 1: 1 kb DNA ladder (Gibco), lajur 2: pET-21CP TICV yang tidak dipotong, lajur 3: pET-21 CP TICV yang dipotong dengan restriksi dan (B) hasil PCR koloni tunggal E. coli rekombinan yang membawa plasmid pET21-CP TICV. lajur 1-5: koloni PCR pET-21 CP TICV dengan sepasang primer spesifik TICV-CP F-BamHI no ATG dan TICV-CP R-HindIII berhasil mengamplifikasi gen CP TICV dengan ukuran 750 bp, lajur 6: 1kb DNA ladder (Gibco)

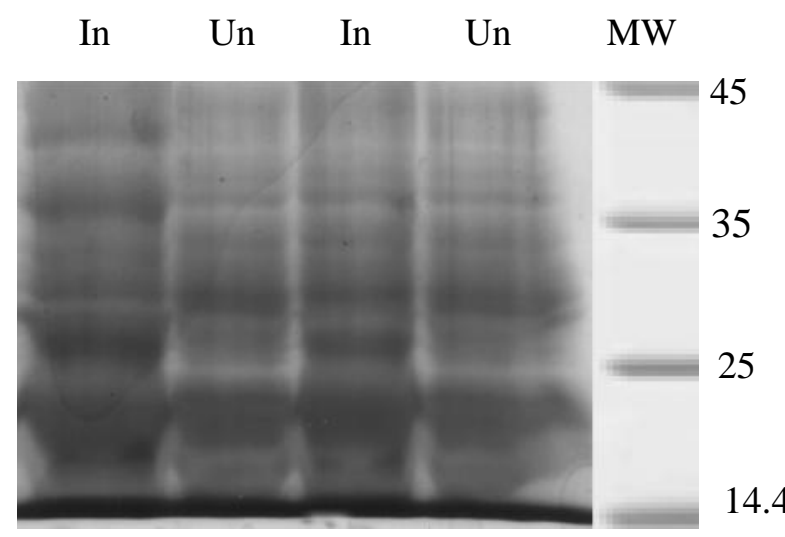

Gambar 5. Analisis SDS-PAGE protein yang diekstraksi dari: kultur bakteri BL21(DE3)pLysS yang mengandung pET 21b-CP TICV yang diinduksi semalaman dengan IPTG $1 \mathrm{mM}$ pada suhu $37^{\circ} \mathrm{C}$ (In), dan tidak diinduksi (Un), MW: berat molekul protein (kDa) (Fermentas)

sekitar $750 \mathrm{pb}$ berhasil diamplifikasi dari koloni tunggal klon rekombinan dengan primer TICV-CP F-Bam no ATG dan TICV-CP R-Hind.

Ekspresi Gen CP TICV. Ekspresi diinduksi dengan penambahan $1 \mathrm{mM}$ IPTG pada biakan bakteri setelah nilai absorbansi pada $\mathrm{OD}_{600}$ mencapai 0,5 . Sistem pengekspresian pET berada dibawah kendali faktor transkripsi T7 dari bakteriofage yang sangat kuat. Aktivitas operon lac dapat diinduksi dengan adanya laktosa dalam media tumbuh. Dalam transformasi, induksi operon lac dilakukan oleh IPTG. IPTG berperan sebagai induser sistem kloning yang terlibat dalam ekspresi lacZ pada plasmid pET-21-CP (Hogg, 2005).
Protein rekombinan yang terekspresi ditranslokasikan ke dalam membran periplasma. Ekstraksi protein dalam membran periplasma dilakukan dengan buffer fosfat yang mengandung urea. Hasil analisis dengan SDSPAGE menunjukkan over ekpresi gen CP TICV dalam sistem ekspresi pET21b (Gambar 5). Pita protein berukuran $29 \mathrm{kDa}$ yang diduga sebagai CP TICV terdeteksi pada klon yang diinduksi dengan IPTG dibanding klon yang tidak diinduksi. Hal ini menunjukkan bahwa gen CP TICV telah berhasil diekspresikan dalam pET21b dengan E. coli strain BL21(DE3)pLysS.

Purifikasi Protein CP-TICV. Purifikasi CP TICV dilakukan dengan NiNTA spin column yang mengandung 


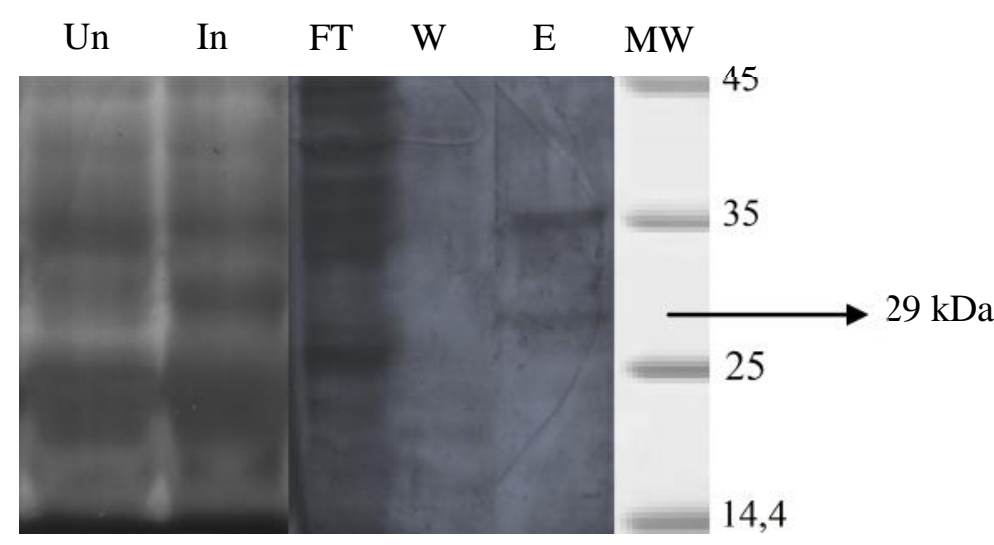

A

B

Gambar 6. (A) Analisis SDS PAGE ekspresi gen CP TICV, In : setelah diinduksi dengan 1 mM IPTG, Un: tanpa diinduksi dengan IPTG. (B) setelah dipurifikasi menggunakan NiNTA spin column. FT: flow through (protein yang lolos dari NiNTA spin column, $\mathrm{W}$ : setelah dicuci dengan buffer $\mathrm{C}, \mathrm{E}$ : hasil elusi dengan NiNTA spin column, MW: berat molekul protein (kDa) (Fermentas)

his-trap di dalam resinnya. Protein CP TICV yang mengandung 6xHistag pada ujung $\mathrm{N}$ sikuen asam aminonya dapat diikat oleh his-trap, sedangkan protein lainnya akan terlepas. Setelah melalui proses pencucian, protein rekombinan dalam his-trap dilepaskan dengan menggunakan buffer $\mathrm{E}$ ( $8 \mathrm{M}$ urea, $0,1 \mathrm{M} \mathrm{NaH}_{2} \mathrm{PO}_{4}, 0,01$ Tris-Cl pH 4,5) sehingga didapatkan protein CP TICV murni (Gambar 6).

\section{SIMPULAN}

Gen CP TICV berhasil diekspresikan pada Escherichia coli strain BL21(DE3)pLysS setelah diinduksi menggunakan IPTG $1 \mathrm{mM}$ selama satu malam pada suhu $37^{\circ} \mathrm{C}$ menunjukkan pita protein yang berukuran sekitar $29 \mathrm{kDa}$, serta berhasil dipurifikasi dengan NiNTA spin column.

\section{SANWACANA}

Kami mengucapkan terimakasih kepada Prof. Tomohide Natsuaki dari Utsunomiya University Jepang yang telah mendanai penelitian ini. Dr. Tri Puji Prayitno dan Dr. Ifa Manzila dari BB-BIOGEN Cimanggu, Bogor yang telah membantu dalam penelitian ekspresi gen ini.

\section{DAFTAR PUSTAKA}

Cotillon AC, Desbiez C, Bouyer S, Wipf-Scheibel C, Gros C, Delécolle B, \& Lecoq H. 2005. Production of a polyclonal antiserum against the coat protein of Cucurbit yellow stunting disorder crinivirus expressed in Escherichia coli. EPPO Bull. 35(1): 99-103.
Duffus JE, Liu HY, \& Wisler GC. 1996. Tomato infectious chlorosis virus-a new clostero-like virus transmitted by Trialeurodes vaporariorum. Eur. J. Plant Pathol. 102(3): 219-226.

Fitriasari ED. 2010. Keefektifan kutu kebul dalam menularkan virus penyebab penyakit kuning pada tanaman tomat. Tesis. Sekolah Pasca Sarjana Institut Pertanian Bogor, Bogor.

Hartono S \& Wijonarko A. 2007. Biomolecular characterization of Tomato infectious chlorosis virus caused yellowing disease on tomato plants in Indonesia. J. Akta Agros Spec. 2: 139-146.

Hogg S. 2005. Essential Microbiology. John Wiley \& Sons., Ltd, The Atrium, Southern Gate, Chichester, West Sussex.

Jacquemond M, Verdin E, Dalmon A, Guilbaud L, \& Gognalons P. 2009. Serological and molecular detection of Tomato chlorosis virus and Tomato infectious chlorosis virus in tomato. Plant Pathol. 58(2): 210-220.

Kurniawati F, Suastika G, \& Giyanto. 2015. Identifikasi tomato infectious chlorosis virus penyebab penyakit klorosis pada tanaman tomat di Cipanas Jawa Barat melalui perunutan nukleotida gen protein selubung utama. J. HPT Tropika 15(1): 33-43.

Laemmli UK. 1970. Cleavage of structural protein during the assembly of the head of bacteriophage T4. Nature 227: 680-685. 
Nishimura M, Park G, \& Xu JR. 2003. The G-beta subunit $M G B 1$ is involved in regulating multiple steps of infection-related morphogenesis in Magnaporthe grisea. Mol. Microbiol. 50(1): 231243.

Qiagen. 2003. The Qiaexpressionist: a Handbook for High Level Expression and Purification of 6xHistagged Protein. Qiagen Inc., Valencia.

Qiagen. 2008. Ni-NTA Spin Kit Handbook. Ed ke-2. Qiagen Inc. Valencia.
Sa'adah L. 2013. Uji serologi diferensial dan simultan untuk Tomato chlorosis virus (ToCV) dan Tomato infectious chlorosis virus (TICV) pada tanaman tomat. Skripsi. Institut Pertanian Bogor, Bogor.

Sambrook J \& Russel DW. 2001. Molecular Cloning: a Laboratory Manual. Cold Spring Harbor Laboratory, New York.

Wisler GC, Duffus JE, Liu HY, \& Li RH. 1998. Ecology and epidemiology of whitefly-transmitted closteroviruses. Plant Dis. 82(3): 270-280. 